\title{
Afectación de la propiedad privada por la incautación de bienes y otras medidas cautelares reales en la jurisprudencia de la Corte Interamericana de Derechos Humanos**
}

\section{Affectation of private property by seizure of assets and other real precautionary measures in de jurisprudence of the Inter-American Court of Human Rights}

RESUMEN

El presente artículo trata acerca de la jurisprudencia de la Corte Interamericana de Derechos Humanos en materia de afectaciones al derecho de propiedad privada, derivadas de la actividad judicial interna de los Estados miembros, con ocasión de incautaciones de bienes y otras medidas cautelares reales. Con este propósito, el autor analiza las sentencias de fondo relativas a esta materia dictadas por la Corte en causas contenciosas desde el año 1993 en adelante, las que se presentan en forma cronológica y acompañadas de una revisión doctrinaria. El objetivo de este trabajo es determinar la visión de la Corte sobre los límites y condiciones a que debe sujetarse el ejercicio de la tutela cautelar estatal para no transgredir la garantía a la propiedad consagrada en la Convención Americana sobre Derechos Humanos.

PALABRAS CLAVE

Propiedad, incautación de bienes, medidas cautelares, jurisprudencia, Corte Interamericana de Derechos Humanos.

Profesor de Derecho Administrativo, Escuela de Derecho, Universidad de Tarapacá (Arica, Chile). Doctorando en Derecho, Universidad de los Andes, Chile; abogado, licenciado en Ciencias Jurídicas de la Universidad de Tarapacá, y magíster en Ciencias Jurídicas, Universidad de Tarapacá. Contacto: pponce@academicos.uta.cl ORCID: 0000-0003-0812-5986.

** Recibido el 5 de noviembre de 2019, aprobado el 12 de junio de 2020.

Para citar el artículo: PonCE CORREA, P. Afectación de la propiedad privada por la incautación de bienes y otras medidas cautelares reales en la jurisprudencia de la Corte Interamericana de Derechos Humanos. En Revista Derecho del Estado, Universidad Externado de Colombia. N. ${ }^{\circ}$ 47, septiembre-diciembre de 2020, 287-317.

DOI: https://doi.org/10.18601/01229893.n47.09 
ABSTRACT

This article deals with the jurisprudence of the Inter-American Court of Human Rights regarding effects on private property, derived from the internal judicial activity of the member states, due to the seizures of property and other real precautionary measures. Analyzes the judgments in this matter, issued by the court in contentious cases from 1993 onwards, which are presented chronologically with a doctrinal review. The objective of this work is to determine the vision of the Court about the limits and conditions to which the exercise of state precautionary protection must be subject, so as not to violate the guarantee of property enshrined in the American Convention on Human Rights.

KEYWORDS

Property, Seizure of property, Precautionary measures, Jurisprudence, InterAmerican Court of Human Rights.

SUMARIO

Planteamiento y metodología. 1. Garantía de la propiedad en la Convención Americana sobre Derechos Humanos. 2. La jurisprudencia de la Corte Interamericana de Derechos Humanos en materia de propiedad. Enunciación. 3. Tutela cautelar y medidas cautelares reales. Delimitación conceptual. 4. Tibi vs. Ecuador, 7 de septiembre de 2004. 5. Palamara Iribarne vs. Chile, 22 de noviembre de 2005. 6. Chaparro Álvarez y Lapo Íñiguez vs. Ecuador, 21 de noviembre de 2007. 7. Familia Barrios vs. Venezuela, 24 de noviembre de 2011. 8. Mémoli vs. Argentina, 22 de agosto de 2013. 9. Andrade Salmón vs. Bolivia, 1 de diciembre de 2016. Conclusión. Referencias.

PLANTEAMIENTO Y METODOLOGÍA

Del universo de 383 sentencias dictadas por la Corte Interamericana de Derechos Humanos (Corte IDH) en asuntos contenciosos al 2 de septiembre de 2019, para la formulación del presente trabajo se consultó un total de 61 fallos correspondientes a casos en los que la Comisión Interamericana de Derechos Humanos o los representantes de las víctimas plantearon discusión relativa a una afectación a la propiedad, sin perjuicio de la existencia de otros derechos involucrados.

Se seleccionó un grupo de 38 sentencias del total anterior, en las que la Corte efectivamente llegó a pronunciarse sobre este derecho, de las cuales 21 corresponden a sentencias de fondo. La presente investigación se formula a partir de estas últimas, las que aparecen referidas en la parte final de este 
trabajo. La Corte Interamericana reconoce en su jurisprudencia la propiedad indígena y tribal como un derecho de carácter colectivo, dotado de atributos diversos a la propiedad privada, de corte individual, lo cual hizo necesario segregar, del señalado grupo de 21 sentencias, aquellas que refieren a la propiedad privada de carácter individual.

El presente trabajo trata específicamente acerca de aquellas sentencias de la Corte en las que se discutió y resolvió una transgresión de la propiedad privada individual con ocasión de la actividad judicial interna de los Estados en relación con medidas cautelares reales. Para ello se emplea una noción amplia de medida cautelar, que incluye medidas aplicadas en cualquier clase de procedimiento, especialmente en los civiles y penales.

De esta manera queda comprendida bajo la noción de medida cautelar real toda afectación preventiva de bienes a un proceso judicial, actual o futuro, tendiente a dotar de eficacia a la decisión definitiva que en este se adopte. Ello incluye la conservación de prueba, el aseguramiento de una ejecución futura, las decisiones interinas en espera de consolidación judicial definitiva y las cauciones fijadas por el juez como condición para autorizar una determinada conducta.

\section{GARANTÍA DE LA PROPIEDAD EN LA CONVENCIÓN \\ AMERICANA SOBRE DERECHOS HUMANOS}

La Convención Americana reconoció entre sus disposiciones el derecho a la propiedad en su artículo $21^{[1]}$, en términos amplios. No obstante, su incorporación al texto definitivo de la Convención fue objeto de profundas discusiones, según ha dado cuenta la propia Corte Interamericana ${ }^{2}$.

$\mathrm{Y}$ es que, si bien la propiedad apareció anteriormente reconocida en el artículo XXIII de la Declaración Americana de Derechos y Deberes del Hombre

1 "Derecho a la Propiedad Privada. / 1. Toda persona tiene derecho al uso y goce de sus bienes. La ley puede subordinar tal uso y goce al interés social. / 2. Ninguna persona puede ser privada de sus bienes, excepto mediante el pago de indemnización justa, por razones de utilidad pública o de interés social y en los casos y según las formas establecidas por la ley. / 3. Tanto la usura como cualquier otra forma de explotación del hombre por el hombre, deben ser prohibidas por la ley".

2 "En el estudio y consideración de los trabajos preparatorios de la Convención Americana sobre Derechos Humanos, el derecho a la propiedad privada fue uno de los más extensamente debatidos en el seno de la Comisión. Desde el primer momento las delegaciones manifestaron la existencia de tres corrientes ideológicas, a saber: una tendencia a suprimir del texto del proyecto toda referencia al derecho de propiedad; otra tendencia a consagrar el texto del proyecto tal y como fue presentado, y una tercera posición conciliadora que reforzaría la función social de la propiedad. Finalmente prevaleció el criterio de incorporar el derecho de propiedad en el texto de la Convención". Comunidad Mayagna (Sumo) Awas Tingni vs. Nicaragua. Fondo, Reparaciones y Costas. Sentencia del 31 de agosto de 2001, párr. 145, n. 57. 
de $1948^{[3]}$, norma esta última que se considera incorporada a la Carta de la Organización de Estados Americanos y, por ello, obligatoria en el contexto interamericano, en general su inclusión en catálogos de derechos humanos ha sido muchas veces objeto de resistencia ${ }^{4}$.

De acuerdo con lo sostenido por la Corte Interamericana en sentencia dictada en el año 2008:

El primer párrafo del artículo 21 de la Convención Americana consagra el derecho a la propiedad privada, y señala como atributos de la propiedad el uso y goce del bien. Incluye a su vez una limitación a dichos atributos de la propiedad en razón del interés social. Este Tribunal ha desarrollado en su jurisprudencia un concepto amplio de propiedad que abarca, entre otros, el uso y goce de los bienes, definidos como cosas materiales apropiables, así como todo derecho que pueda formar parte del patrimonio de una persona. Dicho concepto comprende todos los muebles e inmuebles, los elementos corporales e incorporales y cualquier otro objeto inmaterial susceptible de valor. Asimismo, la Corte ha protegido a través del artículo 21 convencional los derechos adquiridos, entendidos como derechos que se han incorporado al patrimonio de las personas 5 .

La Corte reconoce así un contenido extenso a la propiedad, comprensivo de una serie de relaciones jurídicas patrimoniales, ya sea de carácter colectivo o individual ${ }^{6}$, recaídas tanto sobre bienes corporales como incorporales ${ }^{7}$. Abarca cualquier objeto inmaterial susceptible de valor, lo que ha permitido que la discusión en torno a la propiedad se verifique a propósito de los efectos patrimoniales resultantes de la transgresión de otros derechos ${ }^{8}$.

Más aún, por vía de la garantía a la propiedad, la Corte indirectamente ha otorgado tutela frente a la afectación de derechos de sociedades o personas jurídicas en general, advirtiendo que, bajo ciertas condiciones, estos últimos

3 "Toda persona tiene derecho a la propiedad privada correspondiente a las necesidades esenciales de una vida decorosa, que contribuya a mantener la dignidad de la persona y del hogar".

4 En el mismo sentido, se advierte que la propiedad fue incluida en la Declaración Universal de Derechos Humanos de 1948, pero no apareció en los tratados multilaterales adoptados en el seno de la Organización de Naciones Unidas en 1966 (Pacto Internacional de Derechos Civiles y Políticos, y Pacto Internacional de Derechos Económicos, Sociales y Culturales), lo cual evidencia las enormes dificultades para encontrar consenso al momento de consagrarlo en esta clase de instrumentos. Véase López EsCARCENA, S. La propiedad y su privación o restricción en la jurisprudencia de la Corte Interamericana. En Ius et Praxis. Año 21, n. ${ }^{\circ}$ 1, 2015, 532.

5 Véase Salvador Chiriboga vs. Ecuador. Excepción Preliminar y Fondo. Sentencia del 6 de mayo de 2008, párr. 55.

6 Véase Comunidad Garífuna de Punta Piedra y sus miembros vs. Honduras. Sentencia del 8 de octubre de 2015, párr. 165.

7 Véase Palamara Iribarne vs. Chile. Sentencia del 22 de noviembre de 2005, párr. 102.

8 Así ocurre, por ejemplo, con ocasión de la vulneración de derechos previsionales. Véase Cinco Pensionistas vs. Perú. Sentencia del 28 de febrero de 2003, párr. 102. 
quedan amparados por el derecho de propiedad que les asiste a los accionistas como personas naturales 9 .

De esta manera, si bien el texto de la Convención en materia de propiedad parece acotado y, a simple vista, de menor contundencia frente a la forma y contenido ${ }^{10}$ con que este derecho aparece consagrado en las normas internas de algunos Estados parte, como ocurre en el caso de la Constitución chilena ${ }^{11}$,

$9 \quad$ Véase Ivcher Bronstein vs. Perú. Sentencia del 6 de febrero de 2001, párr. 127.

10 Acerca del contenido del derecho de propiedad como garantía fundamental, véase Evans DE La CuAdra, E. Los derechos constitucionales. T. III. 3. a ed. Santiago: Jurídica de Chile, 1999, 232; Nogueira Alcalá, H. Derechos fundamentales y garantías constitucionales. T. Iv. 2. ${ }^{a}$ ed. Santiago: Librotecnia, 2013, 154; FermandoIs V., A. Derecho constitucional económico. T. II. Santiago: Universidad Católica de Chile, 2010,339; Fuentes Olmos, J. El derecho de propiedad. Santiago: DER, 2018, 257; SANTAELla Quinteros, H. La propiedad privada constitucional: una teoría. Madrid: Marcial Pons, 2019, 110; PeÑaIlillo Arévalo, D. Los bienes. La propiedad y

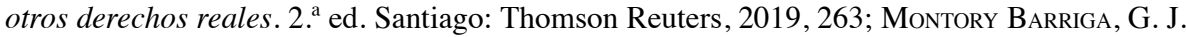
La propiedad constitucional: limitaciones, privaciones, contenido esencial. Valencia: Tirant lo Blanch, 2019, 135; Corral Talciani, H. Curso de derecho civil. Bienes. Santiago: Thomson Reuters, 2020, 102, entre otros.

11 La propiedad privada aparece consagrada especialmente en los números 23, 24 y 25 del artículo 19 de la Constitución Política de la República de Chile de 1980, como un derecho fundamental, ampliamente tutelado, incluso en términos más protectores de los que ofrece el texto de la norma regional en la interpretación de la Corte.

Por ejemplo, en relación con la reserva legal, el órgano jurisdiccional interamericano ha resuelto que "no es necesario que toda causa de privación o restricción al derecho a la propiedad esté señalada en la ley" (Salvador Chiriboga vs. Ecuador. Excepción Preliminar y Fondo. Sentencia del 6 de mayo de 2008, párr. 65), cuestión que resulta improcedente en el sistema chileno. La causal expropiatoria necesariamente debe estar calificada por el legislador (en forma general o especial), en tanto que es el órgano administrativo el que, valiéndose de la autorización legal, procede a ordenar la expropiación. En este sentido, en Chile no resulta admisible que la expropiación sea ordenada enteramente por una ley, así como tampoco que aquella sea decretada exclusivamente por la Administración. Véase CEA EgaÑa, J. L. Tratado de la Constitución de 1980. Santiago: Jurídica de Chile, 1988, 261; CALDERa Delgado, H. Tratado de derecho administrativo. T. II. Santiago: Parlamento, 2001, 402; Vivanco Martínez, Á. Curso de derecho constitucional. Aspectos dogmáticos de la Carta Fundamental de 1980. T. II. Santiago: Universidad Católica de Chile, 2006, 462; Fermandors. Derecho constitucional económico, cit., 392. En este mismo sentido nos pronunciamos en PONCE CORREA, P. La expropiación en su manifestación judicial. Santiago: Librotecnia, 2011, 34 y 421.

Otro aspecto relevante es que la Convención no exige que el pago de la indemnización sea previo a la toma de posesión material. A este respecto, la Corte solo precisa que "el artículo 21 de la Convención hace referencia al pago de una justa indemnización, la cual según este Tribunal deberá ser adecuada, pronta y efectiva". Salvador Chiriboga vs. Ecuador. Excepción Preliminar y Fondo. Sentencia del 6 de mayo de 2008. Voto concurrente del juez Manuel E. Ventura Robles. Por su parte, la norma chilena exige que, a falta de acuerdo con el expropiado, el pago de la indemnización expropiatoria deba practicarse en efectivo, de manera íntegra y en forma previa a la toma de posesión material.

Un último punto relevante se refiere a la titularidad, pues la Constitución chilena garantiza el derecho de propiedad tanto a personas naturales como jurídicas. En la Convención, en cambio, dicha titularidad aparece como controvertida, pues la Corte ha estimado que las personas jurídicas no son reconocidas directamente como titulares de derechos en dicho instrumento. "Ciertamente la Corte ha considerado en casos anteriores que, si bien la figura de las personas jurídicas no ha sido reconocida expresamente por la Convención Americana, como sí lo hace el Protocolo 
bajo la interpretación de la Corte ofrece suficiente flexibilidad para abarcar un amplio espectro de relaciones jurídicas patrimoniales.

\section{LA JURISPRUDENCIA DE LA CORTE INTERAMERICANA DE \\ DERECHOS HUMANOS EN MATERIA DE PROPIEDAD. ENUNCIACIÓN}

La discusión en el Sistema Interamericano de Derechos Humanos versa principalmente sobre afectaciones de derechos de una trascendencia evidentemente mayor, como la vida y la integridad física, de modo que los casos en que la Corte ha llegado a pronunciarse sobre propiedad, al menos en sentencias de fondo, no son numerosos ${ }^{12}$.

Un grupo importante de fallos refiere esencialmente a la propiedad colectiva de comunidades indígenas o tribales ${ }^{13}$, reconocida por el tribunal como una clase diversa a la propiedad privada o individual ${ }^{14}$, respecto de la cual se han formulado anteriormente otros estudios ${ }^{15}$.

n. ${ }^{\circ} 1$ del Convenio Europeo para la Protección de los Derechos Humanos y de las Libertades Fundamentales, eso no restringe la posibilidad de que bajo determinados supuestos un individuo pueda acudir al Sistema Interamericano para hacer valer sus derechos, aun cuando los mismos estén cubiertos por una figura o ficción jurídica creada por el mismo sistema jurídico". Perozo y otros vs. Venezuela. Excepciones Preliminares, Fondo, Reparaciones y Costas. Sentencia del 28 de enero de 2009, párr. 399). Se trata, en todo caso, de un tema en evolución, pues en la Opinión Consultiva OC-22/16 la Corte se abre a reconocer la titularidad de derechos en el caso de los sindicatos y las comunidades indígenas.

12 Sobre los principales casos de propiedad abordados por la Corte véanse EsPEJO YAKSIC, N. y Leiva García, C. Digesto de jurisprudencia de la Corte Interamericana de Derechos Humanos (enero de 1984-febrero de 2012). Santiago: Thomson Reuters, 2012, 537-562; LóPEZ EsCARCENA. La propiedad y su privación o restricción en la jurisprudencia de la Corte Interamericana, cit.

13 Véanse Comunidad Mayagna (Sumo) Awas Tingni vs. Nicaragua. Sentencia del 31 de agosto de 2001; Comunidad Moiwana vs. Suriname. Sentencia del 15 de junio de 2005; Comunidad Indígena Yakye Axa vs. Paraguay. Sentencia del 17 de junio de 2005; Comunidad Indígena Sawhoyamaxa vs. Paraguay. Sentencia del 29 de marzo de 2006; Pueblo Saramaka vs. Surinam. Sentencia del 28 de noviembre de 2007; Comunidad Indígena Xákmok Kásek vs. Paraguay. Sentencia del 24 de agosto de 2010; Pueblo Indígena Kichwa de Sarayaku vs. Ecuador. Sentencia del 27 de junio de 2012; Pueblos Indígenas Kuna de Madungandí y Emberá de Bayano y sus miembros vs. Panamá. Sentencia del 14 de octubre de 2014; Comunidad Garífuna Triunfo de la Cruz y sus miembros vs. Honduras. Sentencia del 8 de octubre de 2015; Comunidad Garífuna de Punta Piedra y sus miembros vs. Honduras. Sentencia del 8 de octubre de 2015; Pueblos Kaliña y Lokono vs. Surinam. Sentencia del 25 de noviembre de 2015.

14 La Corte señala que ambas clases de propiedad están amparadas por el artículo 21 de la Convención, e incluso reconoce que pueden llegar a estar en conflicto, frente a lo cual fija parámetros especiales de protección en favor de la propiedad indígena y tribal; no obstante, ha expresado que "[e]sto no significa que siempre que estén en conflicto los intereses territoriales particulares o estatales y los intereses territoriales de los miembros de las comunidades indígenas, prevalezcan los últimos por sobre los primeros". Véase Comunidad Indígena Yakye Axa vs. Paraguay. Fondo, Reparaciones y Costas. Sentencia del 17 de junio de 2005, párr. 149.

15 Véase Ferrero Hernández, R. Protección de la propiedad comunal indígena por la Corte Interamericana. En Revista IIDH. Vol. 63, 2016, 65-103; LÓPEZ EsCARCENA, S. Un derecho 
Dentro de las sentencias que tratan acerca de la propiedad privada e individual, la mayoría corresponde a afectaciones al domino derivadas de violaciones a otros derechos principales, como la vida ${ }^{16}$, derechos previsionales ${ }^{17} \mathrm{o}$ la libertad de pensamiento y de expresión ${ }^{18}$, entre otros.

Quizá el único caso resuelto por la Corte referido directamente a la propiedad individual como derecho principal afectado corresponde a Salvador Chiriboga vs. Ecuador ${ }^{19}$, que versa sobre un proceso de expropiación. Es a propósito de este último que la Corte formula su mayor exposición en relación a este tema ${ }^{20}$.

Pero un aspecto importante del desarrollo jurisprudencial de la Corte en materia de propiedad corresponde a su afectación por la vía de actuaciones procesales de los tribunales internos. Respecto de estas últimas se ha pronunciado en torno a la excesiva dilación en la resolución de $\operatorname{casos}^{21}$, al incumplimiento de sentencias ${ }^{22} \mathrm{o}$ a la fórmula de cumplimiento dispuesta en el fallo ${ }^{23}$.

El presente trabajo se enfoca específicamente en la jurisprudencia de la Corte concerniente a la transgresión de la propiedad privada derivada de actuaciones procesales consistentes en medidas cautelares reales. En el siguiente acápite intentaremos delimitar el marco conceptual empleado a este respecto, para efectos de este estudio.

\section{TUTELA CAUTELAR Y MEDIDAS CAUTELARES \\ REALES. DELIMITACIÓN CONCEPTUAL}

Entendemos por tutela cautelar aquel aspecto específico de la función jurisdiccional tendiente a la adopción de medidas preventivas y provisionales destinadas a dar efectividad a la decisión definitiva de los asuntos controverti-

jurisprudencial. La propiedad colectiva y la Corte Interamericana. En Revista de Derecho Universidad Católica del Norte. Año 24, n. . 1, 2017, 133-189.

16 Véase Masacres de Ituango vs. Colombia. Sentencia del 1 de julio de 2006; Masacre de Santo Domingo vs. Colombia. Sentencia del 30 de noviembre de 2012.

17 Véase "Cinco Pensionistas" vs. Perú. Sentencia del 28 de febrero de 2003; Acevedo Buendía y otros ('Cesantes y jubilados de la Contraloría') vs. Perú. Sentencia del 1 de julio de 2009.

18 Véase Palamara Iribarne vs. Chile. Sentencia del 22 de noviembre de 2005; Perozo y otros vs. Venezuela. Sentencia del 28 de enero de 2009.

19 Este caso comprende una sentencia de fondo, dictada el 6 de mayo de 2008, una de reparación y costas, del 3 de marzo de 2011, y una de interpretación, del 29 de agosto de 2011.

20 Véase LóPEz ESCARCENA. La propiedad y su privación o restricción en la jurisprudencia de la Corte Interamericana, cit.

21 Véase Salvador Chiriboga vs. Ecuador. Sentencia del 6 de mayo de 2008; Mémoli vs. Argentina. Sentencia del 22 de agosto de 2013.

22 Véase "Cinco Pensionistas" vs. Perú. Sentencia del 28 de febrero de 2003; Abrill Alosilla y otros vs. Perú. Sentencia del 4 de marzo de 2011.

23 Véase Abrill Alosilla y otros vs. Perú. Sentencia del 4 de marzo de 2011 y más claramente en Furlan y Familiares vs. Argentina. Sentencia del 31 de agosto de 2012. 
dos sometidos al conocimiento de un tribunal ${ }^{24}$. Tratándose de una afectación preventiva, quedan excluidas de esta noción las medidas de ejecución ${ }^{25}$.

Nuestro estudio se refiere esencialmente a la jurisprudencia de la Corte en materia de propiedad, de modo que el presente trabajo aborda exclusivamente aquel aspecto de la tutela cautelar que concierne a medidas de carácter real, esto es, aquellas que despliegan efectos respecto del ámbito patrimonial y no de la persona del afectado.

Para ello hemos empleado un concepto amplio de medida cautelar real, que incluye toda forma de afectación procesal preventiva de bienes, respecto de un proceso actual o futuro, que busca dotar de eficacia a la decisión definitiva que en este se adopte ${ }^{26}$, cualquiera sea el procedimiento de que se trate, tanto en el ámbito civil como penal.

Siguiendo a Calamadrei ${ }^{27}$, diremos que, según su propósito, las medidas cautelares reales admiten ser divididas en cuatro clases: 1 . La conservación de prueba; 2. El aseguramiento de una ejecución futura; 3. Las decisiones

24 Aclara Quezada Meléndez que, mientras Calamandrei centra la atención en la "providencia", Chiovenda en la "acción" y Carnelutti en "el proceso cautelar", parece preferible entender las medidas cautelares como una expresión propia de la jurisdicción. Véase QuEZADA MelénDEZ, J. Derecho procesal civil chileno. La jurisdicción. Santiago: Ediar, 1984, 28. En el mismo sentido, anota Pereira Anabalón que, además del conocimiento, juzgamiento y ejecución de las causas civiles y criminales, el ejercicio de la jurisdicción se manifiesta también en la función cautelar, que goza de caracteres propios y diferenciados. Véase Pereira Anabalón, H. Curso de derecho procesal. T. I. Santiago: Jurídica Conosur, 1993, 118. Por esta razón, se colige que la tutela cautelar forma parte integrante de la tutela judicial efectiva y deriva del "derecho a la efectividad de las resoluciones judiciales". Véase Cortez MAтCOVICH, G. Tutela cautelar en el proceso civil. Santiago: Thomson Reuters, 2017, 40.

25 Cabe advertir que, si bien presentan ciertas similitudes materiales, la doctrina procesalista diferencia las medidas cautelares de las de ejecución. En ambos casos se trata de actuaciones instrumentales al proceso, de caracteres homogéneos, pero responden a finalidades distintas. Las primeras tienen como base un fumus boni iuris, en tanto las segundas descansan en el efecto de la cosa juzgada, esto es, se refieren a un derecho ya establecido e indiscutible. Véase CALAMANDREI, P. Introducción al estudio sistemático de las providencias cautelares. Santiago: Olejnik, 2018, 111-114. Acerca de la relación de homogeneidad entre medidas cautelares y ejecutivas, véase CALDERÓN CUADRADO, M. P. Las medidas cautelares indeterminadas en el proceso civil. Madrid: Civitas, 1992, 59-62; así también Jové, M. Á. Medidas cautelares innominadas en el proceso civil. Barcelona: Bosch, 1995, 20-28. Por este motivo, el embargo de bienes solo posee naturaleza cautelar cuando ha sido decretado con carácter preventivo, en aquellos sistemas en que se tolera esta posibilidad. Véase Pérez Ragone, Á. y Hormazábal Riquelme, D. El embargo de cuentas bancarias. En Revista de Derecho Universidad Católica del Norte. Año 22, n. ${ }^{\circ} 1$, 2015, 307-350.

26 Precisa Chiovenda que esta clase de medidas responden a la necesidad actual y efectiva de remover el temor respecto de un determinado daño jurídico; ahora, si este daño jurídico es en realidad inminente, ha de resultar una declaración definitiva. En este sentido, para dicho autor, la medida cautelar es una forma autónoma de acción (acción garantizadora) y no puede considerare accesoria del derecho tutelado. Véase ChIOvenda, J. Principios de derecho procesal civil. T. I. 3. a ed. Trad. J. Casais y Santaló. Madrid: Reus, 1922, 262.

27 Véase CALAMANDREI. Introducción al estudio sistemático de las providencias cautelares, cit., 53-68. 
interinas en espera de consolidación judicial definitiva, y 4. Las cauciones fijadas por el juez como condición para autorizar una determinada actuación ${ }^{28}$. Se suele distinguir, además, entre nominadas e innominadas ${ }^{29}$.

Lo anterior comprende incautaciones, prohibiciones de enajenar o de gravar, fianzas, medidas precautorias en general, y cualquier otra medida judicial destinada a limitar o restringir el ejercicio dominical de un particular sobre bienes determinados, con el propósito de asegurar la efectividad de una actividad jurisdiccional concreta.

Se trata en estos acasos de medidas provisionales, pues son actuaciones cuya duración está limitada en el tiempo, no de situaciones definitivas y perdurables ${ }^{30}$. Son instrumentales, pues se establecen en relación con un proceso, ya sea en cuanto a la finalización del mismo o a su no iniciación ${ }^{31}$. Y son medidas de carácter urgente, pues de lo contrario no habría necesidad de adoptarlas en forma previa a la decisión definitiva ${ }^{32}$.

A las anteriores características agrega Orellana Torres que se trata de medidas acumulables, en tanto puede aplicarse más de una medida cautelar en un caso concreto; sustituibles, pues pueden ser reemplazadas por otras que

28 Ortells Ramos y Calderón Cuadrado clasifican las medidas cautelares desde la perspectiva de sus efectos, agrupándolas en tres clases: 1. Las de aseguramiento, que buscan mantener una situación adecuada a fin de que los efectos de la sentencia definitiva que se dicte en el proceso puedan desarrollarse efectivamente; 2 . Las de conservación y no simple aseguramiento, que buscan mantener el statu quo previo al conflicto, pero con un grado de injerencia superior a las anteriores, lo que se aproxima a la satisfacción de la pretensión que se discute en el proceso principal, y 3. Las innovativas y derechamente anticipativas de la satisfacción de la pretensión principal, que no buscan mantener el statu quo sino introducir un cambio o innovación en la situación fáctica a fin de satisfacer de manera interina la pretensión discutida en el proceso principal. Véase Ortells Ramos, M. y Calderón Cuadrado, M. P. La tutela judicial cautelar en el derecho español. Granada: Comares, 1996, 17-20. En idéntico sentido, véase OrTELLs Ramos, M. Las medidas cautelares. Madrid: La Ley, 2000, 138-145. En atención exclusiva a la relación que mantienen con la ejecución, Roy Pérez clasifica las medidas cautelares en dos: conservativas, las cuales paralizan la situación actual a fin de garantizar la ejecución ulterior, sin perjuicio de llegar a anticipar algunos de sus efectos, y propiamente anticipativas, que constituyen una ejecución adelantada, pues despliegan efectos similares a los que se derivarían de existir una decisión judicial favorable de fondo. Véase Roy Pérez, C. Las medidas cautelares en el proceso civil. Barcelona: Bosch, 2007, 8-9.

29 En atención a que las medidas cautelares tipificadas por la norma no son taxativas. Véase Pereira Anabalón. Curso de derecho procesal, cit., 121.

30 No hablamos de temporalidad, pues esta última solo refiere a algo que dura un tiempo determinado, que no es eterno, mientras que la provisoriedad constituye un concepto más restringido, que alude a algo que está destinado a mantenerse en el tiempo en tanto no sobrevenga un evento sucesivo determinado. Se puede considerar que toda providencia cautelar lleva ínsita la cláusula rebus sic stantibus. Véase CALAMANDREI. Introducción al estudio sistemático de las providencias cautelares, cit., 36 .

31 Véase CALDERÓN CUADRADO. Las medidas cautelares indeterminadas en el proceso civil, cit., 34 .

32 Véase Carnelutti, F. Instituciones del proceso civil. Vol. III (1956). 5. a ed. Trad. S. Sentís Melendo. Buenos Aires: EJEA, 1973, 218. 
resulten menos inconvenientes para el afectado $^{33}, \mathrm{y}$ limitadas, ya que no pueden abarcar íntegro el patrimonio del afectado, sino solo bienes determinados ${ }^{34}$.

A continuación desarrollaremos en orden cronológico los pronunciamientos emitidos por la Corte en sentencias de fondo relativas a la afectación de la propiedad privada derivada de actuaciones de los tribunales internos de los Estados miembros de la Convención, respecto de la aplicación de medidas cautelares reales.

\section{TIBI VS. ECUADOR, 7 DE SEPTIEMBRE DE 2004}

El señor Tibi era comerciante de piedras preciosas. En septiembre de 1995, mientras conducía su automóvil, fue arrestado en la ciudad de Quito por agentes policiales, sin orden judicial y con el solo mérito de la declaración inculpatoria de un tercero. Tras su detención fue llevado en avión a otra ciudad, ubicada aproximadamente a 600 kilómetros de distancia, en donde fue ilegalmente recluido por veintiocho meses.

Fue torturado en varias ocasiones, golpeado, quemado y asfixiado para obligarlo a confesar su participación en un caso de narcotráfico del que reiteradamente afirmó ser inocente. El proceso penal concluyó con el sobreseimiento del señor Tibi en 1998, luego de que un tercero, que lo había inculpado originalmente, se retractara de su declaración.

En cuanto a la propiedad, el reproche versa sobre el hecho de que al momento de su detención le fueron incautados al inculpado su automóvil y una serie de bienes que portaba en ese momento, valorados en un millón de francos franceses. Tras ser liberado en enero de 1998, los bienes incautados no le fueron devueltos pues, a juicio del Estado, la víctima no acreditó su dominio en la etapa procesal respectiva.

En los párrafos 213 a 221 de la sentencia la Corte sostiene que el inculpado no está en la necesidad de acreditar el dominio sino únicamente la posesión de tales bienes, y concluye que esta última se encuentra amparada por el artículo 21 de la Convención.

Se ha probado que fueron incautadas las pertenencias que el señor [D.] Tibi tenía en su poder al momento de su detención [...].

33 Anota Ortells Ramos que la sustitución de una medida cautelar por caución se encuentra consagrada en términos generales. Pese a ello, el juez no se encuentra vinculado por el ofrecimiento de caución, correspondiéndole fijar su cuantía y calificar si esta resulta suficiente para garantizar adecuadamente el cumplimiento de la sentencia. Véase OrTELLs RAMOs. Las medidas cautelares, cit., 194-200.

34 Véase Orellana Torres, F. Manual de derecho procesal. T. II, Procedimientos civiles ordinarios y especiales. Santiago: Librotecnia, 2008, 162. 
[...] el señor Tibi se hallaba en una posesión no controvertida de los bienes al momento de su detención. Dicha posesión fue documentada por un agente estatal cuando levantó la correspondiente acta [...].

[...] la posesión establece por sí sola una presunción de propiedad a favor del poseedor y, tratándose de bienes muebles, vale por título. Esta Corte considera que el artículo 21 de la Convención protege el derecho a la propiedad en un sentido que comprende, entre otras cosas, la posesión de los bienes.

[...] En suma, los bienes incautados al señor Tibi, al momento de la detención, se encontraban bajo su uso y goce. Al no serle devueltos, se le privó de su derecho a la propiedad. El señor Tibi no estaba obligado a demostrar la preexistencia ni la propiedad de los bienes incautados para que estos le fueran devueltos.

De acuerdo a lo sustentado por la Corte, no corresponde a los tribunales condicionar la devolución de las especies muebles incautadas a la acreditación previa de la titularidad de su propiedad por el afectado, pues la posesión de ellas al momento de la incautación permite presumir tal condición.

Por esta vía la Corte considera que la posesión, que, por definición, corresponde a una situación fáctica, consistente en la tenencia acompañada del ánimo de dueño (apariencia de dominio), se encuentra igualmente amparada por la Convención. Así, quien goza de la posesión de ciertos bienes al momento de practicarse una medida cautelar, se halla amparado en esa situación de hecho, de lo que surge el derecho a recuperarla una vez cesada la medida.

Cabe observar que el caso en comento refiere exclusivamente a bienes muebles. Surge así la duda acerca de si la misma conclusión puede extraerse en el evento de que la incautación recaiga sobre inmuebles, ya que la posesión de esta clase de bienes se encuentra generalmente sujeta a un sistema registral.

No obstante, dentro de las especies incautadas en este caso se halla un vehículo cuyo dominio, bajo la legislación ecuatoriana, se sujeta a un régimen especial de inscripción. Más aún, dicho automóvil figuraba registrado a nombre de un tercero, el cual no compareció judicialmente a fin de solicitar su restitución. La Corte aplica la misma solución anterior, pero añade como elemento adicional la falta de oposición de tercero contradictor. Así lo expresa en el párrafo 219:

Por lo que toca al automóvil que conducía el señor Tibi cuando fue detenido, si bien se trata de un bien mueble registrable, este registro es necesario para el solo efecto de la oponibilidad ante el reclamo de un tercero que pretende tener algún derecho sobre el bien. En el presente caso no consta que persona alguna haya reclamado la propiedad del automóvil que se encontraba en poder del señor Tibi, por lo cual no debería presumirse que no le pertenecía dicho bien. En consecuencia, era procedente respetar la posesión que ejercía. 
De esta manera, el razonamiento de la Corte parece extensible, prima facie, a los inmuebles u otros bienes sujetos a registro, en tanto la inscripción sea considerada únicamente como requisito de oponibilidad. No obstante, no nos parece tan clara la posibilidad de extrapolar esta conclusión a aquellos sistemas en que la inscripción conservatoria se dispone como requisito para adquirir la posesión, como acontece muchas veces con los inmuebles ${ }^{35}$.

De esta manera, parece importante observar la evolución de este criterio en la jurisprudencia futura de la Corte, a fin de determinar con claridad si será extensible a los bienes sujetos a posesión inscrita o a otra clase de bienes en los que dicha formalidad constituya un requisito sine qua non de la posesión.

\section{PALAMARA IRIBARNE VS. CHILE, 22 DE NOVIEMBRE DE 2005}

El señor Palamara Iribarne es un oficial retirado de la Armada de Chile, autor del libro Ética y Servicios de Inteligencia, "en el cual abordaba aspectos relacionados con la inteligencia militar y la necesidad de adecuarla a ciertos parámetros éticos". En marzo de 1993 el Estado de Chile prohibió la publicación de dicha obra e incautó sus originales y ejemplares, un disco que contenía el texto íntegro de la obra y la matricería electroestática. Asimismo, forzó la eliminación del texto completo del libro desde el disco duro de la computadora personal del señor Palamara, la cual se encontraba en su domicilio.

El afectado fue sometido a proceso y condenado por "dos delitos de desobediencia". Además, "dio una conferencia de prensa producto de la cual fue procesado y en definitiva condenado por el delito de desacato". La Corte juzgó este caso como una violación a la libertad de pensamiento y de expresión, y en el párrafo 78 de la sentencia concluyó que la incautación, la destrucción y la prohibición de publicación de la obra constituyeron actos de censura previa por parte del Estado:

La Corte considera que, en las circunstancias del presente caso, las medidas de control adoptadas por el Estado para impedir la difusión del libro "Ética y Servicios de Inteligencia" del señor Palamara Iribarne constituyeron actos de censura previa no compatibles con los parámetros dispuestos en la Convención, dado que no existía ningún elemento que, a la luz de dicho tratado, permitiera que se afectara el referido derecho a difundir abiertamente su obra, protegido en el artículo 13 de la Convención.

35 Así por ejemplo, en el sistema chileno, la posesión de los inmuebles inscritos que deviene de un título traslaticio solo se adquiere por la respectiva inscripción conservatoria. Véase Vodanovic Haklicka, A. Tratado de los derechos reales. Bienes. T. I. Basado en las explicaciones de clases de Arturo Alessandri Rodríguez y Manuel Somarriva Undurraga. 7. a ed., Santiago: Jurídicas de Santiago, 2016, 422. 
Sobre la base de esa lógica analiza la Corte tales actos como una afectación de la propiedad en los siguientes términos. En primer lugar, en el párrafo 193 concluye que el derecho de autor es amparado por la Convención dentro de la garantía a la propiedad:

La protección del uso y goce de la obra confiere al autor derechos que abarcan aspectos materiales e inmateriales. El aspecto material de estos derechos de autor abarca, entre otros, la publicación, explotación, cesión o enajenación de la obra y, por su parte, el aspecto inmaterial de los mismos se relaciona con la salvaguarda de la autoría de la obra y la protección de su integridad. El aspecto inmaterial es el vínculo entre el creador y la obra creada, el cual se prolonga a través del tiempo. Tanto el ejercicio del aspecto material como [el] del aspecto inmaterial de los derechos de autor son susceptibles de valor y se incorporan al patrimonio de una persona. En consecuencia, el uso y [el] goce de la obra de creación intelectual también se encuentran protegidos por el artículo 21 de la Convención Americana ${ }^{36}$.

Luego de resolver que los actos desarrollados por el Estado de Chile en este caso constituyeron una privación del derecho de propiedad, en el párrafo 108 la sentencia analiza las condiciones que debe cumplir tal privación para que se encuentre emparada por la Convención:

La Corte observa que el derecho a la propiedad no es un derecho absoluto y que el artículo 21.2 de la Convención establece que para que la privación de los bienes de una persona sea compatible con el derecho a la propiedad consagrado en la Convención, debe fundarse en razones de utilidad pública o de interés social, sujetarse al pago de una justa indemnización, limitarse a los casos y practicarse según las formas establecidas por la ley. Debido a las circunstancias del presente caso, el Tribunal considera que es evidente que el señor Palamara Iribarne no ha sido indemnizado por el Estado por la privación del uso y goce de sus bienes.

Por último, en el párrafo 109 la Corte constata:

Las sentencias emitidas por el Juzgado Naval de Magallanes y por la Corte Marcial de la Armada, al pronunciarse sobre los delitos de desobediencia e incumplimiento de los deberes militares, no hace[n] referencia a los intereses que fundamentaron la prohibición de la publicación del referido libro [...] La

36 Resulta relevante advertir que la Corte considera amparado por la propiedad no solo el contenido material del derecho de autor, de carácter eminentemente patrimonial, sino además el contenido moral, conformado por la paternidad y la integridad de la obra, las cuales no poseen un carácter directamente económico. Acerca del contenido del derecho de autor véase WALKER Echenique, E. Manual de propiedad intelectual. Santiago: Legal Publishing Chile, 2014, 145193. 
Corte estima que la privación de la propiedad con fundamento en un "interés institucional" es incompatible con la Convención.

De esta forma, la Corte analiza la privación de la propiedad derivada de la incautación, comiso y subsecuente prohibición de publicación de una obra, al alero del artículo 21 de la Convención, como un caso de expropiación material ${ }^{37}$ que, al no cumplir con los parámetros de utilidad pública o interés social previstos en dicha norma, deviene en ilegítima.

Lo anterior se debe a que la sentencia determina que el derecho de autor constituye una clase de propiedad y, por tanto, se encuentra amparado por la garantía del artículo 21. Conclusión esta última a la que arriba por medio de una interpretación extensiva, más allá del texto de la Convención. Esto nos confirma nuevamente la mirada amplia que tiene la Corte en esta materia y el contenido flexible que atribuye al derecho de propiedad.

No obstante, en este caso no consideramos acertado recurrir a la expropiación como fundamento de la obligación estatal de reparar la afectación dominical, por cuanto parece centrar el reproche en la mera ausencia de una compensación económica y sentar la idea de que toda privación estatal de la propiedad entraña un deber objetivo de indemnizar, cuestión que no es efectiva.

Si bien la redacción de la garantía a la propiedad en el artículo 21.2 de la Convención refiere a la privación de la propiedad ${ }^{38}$, lo que nos sitúa en el campo de las potestades ablatorias reales ${ }^{39}$, únicamente hace alusión a aquellas facultades estatales cuyo sustento se halla en la necesidad pública de adquirir un determinado bien, como la expropiación, la nacionalización o la requisición ${ }^{40}$, las cuales conllevan un deber de compensar la pérdida patrimonial ocasionada.

37 Entendemos que se produce una expropiación material cada vez que existe un acto estatal privativo y correlativamente adquisitivo de la propiedad privada, dispuesto como ejercicio potestativo exclusivo del Estado con la finalidad de premunirse de un determinado bien, sin cumplir los requisitos constitucionales para el ejercicio de la potestad expropiatoria. "Tal supuesto se puede concretar de dos formas: normativa, cuando la privación se produce por la sola dictación de una o más reglas jurídicas, cualquiera sea su jerarquía, que directamente privan o inhiben el ejercicio del dominio particular en favor del Estado; o funcional, cuando una norma general autoriza la ulterior actuación de un órgano estatal, siendo esta última la que priva o afecta materialmente el dominio". PONCE CORREA. La expropiación en su manifestación judicial, cit., 467.

38 Artículo 21.2: "Ninguna persona puede ser privada de sus bienes, excepto mediante el pago de indemnización justa, por razones de utilidad pública o de interés social y en los casos y según las formas establecidas por la ley".

39 Entendemos por potestad ablatoria real la privación forzosa de la propiedad de un particular y la subsecuente adquisición por la Administración del Estado, o por particulares legitimados por esta última. Véase García de Enterría, E. y Fernández, T. R. Curso de derecho administrativo. T. II. 15. ${ }^{\text {a }}$ ed. Madrid: Thomson Civitas, 2006, 120.

40 En una sentencia posterior, al referirse a texto del numeral 2 del artículo 21 de la Convención, la Corte precisa su contenido en los siguientes términos: "A su vez, el segundo inciso se refiere a la expropiación de bienes y los requisitos para que tal actuar del Estado pueda 
Pero existen potestades ablatorias de carácter sancionatorio cuyo ejercicio obedece al ius puniendi del Estado, como acontece con el comiso y la confiscación. Su aplicación no se origina en la necesidad pública de adquirir un bien sino en el actuar antijurídico del propio afectado, de modo que no conllevan un deber de reparar a este último el daño patrimonial ocasionado, en tanto el despliegue punitivo estatal sea legítimo.

Se observa que la sentencia en comento no solo reprocha las actuaciones cautelares, que califica como una censura previa, sino también la sanción misma aplicada al afectado, quien resultó condenado como autor de tres delitos diversos. Pese a ello, la Corte no infiere per se un deber compensatorio del comiso, sino que lo hace a partir de la aplicación concreta del tipo penal previsto en la norma chilena, que estimó atentatoria de la libertad de pensamiento y expresión.

Por tanto, el deber de reparación que la Corte reconoce en favor del afectado, en este caso, se sustenta en la responsabilidad patrimonial del Estado por la privación de la propiedad particular como consecuencia de la afectación ilegítima de la libertad de pensamiento y de expresión, no como un deber objetivo de compensación derivado de la sola privación de dominio sufrida.

Así, pese al texto del artículo 21.2 de la Convención, una interpretación más detenida nos fuerza a concluir que no toda privación estatal de la propiedad requiere ser indemnizada. Lo contrario implicaría equiparar "ablación dominical" con "potestad expropiatoria" y, desde esa perspectiva, tener que calificar cualquier afectación estatal de la propiedad como una expropiación material, sujeta a compensación; conclusión esta última que no resulta razonable.

6. CHAPARRO ÁLVAREZ Y LAPO ÍÑIGUEZ VS.

ECUADOR, 21 DE NOVIEMBRE DE 2007

La controversia se refiere a la responsabilidad internacional del Estado de Ecuador por la detención e incautación de bienes de los señores Chaparro Álvarez y Lapo Íñiguez, como sospechosos de la comisión de delitos de narcotráfico. El primero era dueño de una fábrica dedicada a la elaboración de hieleras para el transporte y exportación de productos, mientras que el segundo era un trabajador de la misma empresa.

La discusión central gira en torno a la legalidad y fundamento de la detención de ambos, así como a la extensión del período por el cual permanecieron privados de la libertad, junto con la transgresión de otras garantías procesales. En lo que concierne a la propiedad, el reproche versa sobre la incautación de bienes que sufrió cada cual, así como sobre su fundamento,

considerarse justificado". Andrade Salmón vs. Bolivia. Fondo, Reparaciones y Costas. Sentencia del 1 de diciembre de 2016, párr. 111. 
pues las diligencias investigativas y los peritajes efectuados no condujeron al hallazgo de droga.

Chaparro Álvarez sufrió el allanamiento e incautación de su fábrica, la cual le fue devuelta 5 años más tarde, con algunos bienes defectuosos y otros faltantes. Además, para su entrega, se le exigió el pago previo de una cantidad de dinero por concepto de "liquidación por derechos de depositario". Y, en el caso del señor Lapo Íñiguez, este último sufrió la incautación de su vehículo, el cual no le fue devuelto.

En primer término, el párrafo 174 de la sentencia reconoce el carácter limitado del derecho de propiedad:

La Corte observa, sin embargo, que el derecho a la propiedad no es un derecho absoluto, pues en el artículo 21.2 de la Convención se establece que para que la privación de los bienes de una persona sea compatible con el derecho a la propiedad debe fundarse en razones de utilidad pública o de interés social, sujetarse al pago de una justa indemnización, limitarse a los casos, practicarse según las formas establecidas por la ley y efectuarse de conformidad con la Convención.

En los párrafos 187 y 188 de la sentencia, la Corte concluye que las medidas cautelares no constituyen una privación del domino en sí mismas, en los siguientes términos:

Este Tribunal estima que la adopción de estas medidas [cautelares reales] no constituye per se una violación del derecho de propiedad si se tiene en cuenta que no significa un traslado de la titularidad del derecho de dominio. En este sentido, la disposición de los bienes no puede efectuarse en forma definitiva y se restringe exclusivamente a su administración y conservación; y a los actos de investigación y manejo de evidencia respectivos.

En estas líneas la Corte reconoce que las medidas cautelares reales entrañan una afectación del derecho de propiedad pues, si bien no configuran una privación definitiva del dominio, limitan la facultad de disposición de los bienes, su administración y conservación. No obstante, tal actuación no es en sí ilegítima; el Estado se encuentra autorizado para decretarlas, sujeto a condiciones que justifiquen su aplicación.

[L]a adopción de medidas cautelares reales debe justificarse previamente en la inexistencia de otro tipo de medidas menos restrictivas del derecho a la propiedad. [...] [S]ólo es admisible la aprehensión y depósito de bienes frente a los cuales se encuentran indicios claros de su vinculación con el ilícito, siempre y cuando ello sea necesario para garantizar la investigación, el pago de las responsabilidades pecuniarias a que haya lugar o evitar la pérdida o deterioro de la evidencia $[\ldots]$ teniendo en cuenta que si desaparecen las razones que justificaron la medida precautoria, el juez debe valorar la pertinencia de continuar con la restricción, 
aún antes de la finalización del proceso. Este punto es de la mayor importancia, dado que si los bienes no siguen cumpliendo un papel relevante para continuar o impulsar la investigación, la medida cautelar real debe ser levantada, so pena de convertirse en una pena anticipada. Este último evento constituiría una restricción manifiestamente desproporcionada del derecho a la propiedad.

Y concluye más adelante:

[A]l ejercer la facultad de dictar las medidas cautelares de carácter real contempladas en la ley, las autoridades nacionales están obligadas a dar razones que justifiquen la medida como adecuada. Ello exigía precisar la "apariencia de buen derecho", esto es, que existían probabilidades e indicios suficientes para inferir que los bienes estaban realmente involucrados en el ilícito.

En estos párrafos la Corte deja entrever una serie de exigencias a que se sujeta la tutela cautelar. En primer término, y en línea con la doctrina procesalista, plantea que estas medidas deben sustentarse en un fumus boni iuris, esto es, una apariencia de buen derecho ${ }^{41}$. Es decir, que con ellas se busca amparar una situación que, al menos en principio, se vislumbra como jurídicamente cautelable; en otras palabras, plantea una exigencia de verosimilitud del derecho alegado ${ }^{42}$.

Para determinar la existencia de un fumus boni iuris no basta la predisposición intuitiva del tribunal, sino que dicha situación debe estar apoyada en antecedentes que avalen tal presunción, al menos de carácter indiciario. Por ello la Corte exige en este caso que concurran "indicios claros".

La aplicación de estas medidas debe resultar necesaria a fin de precaver un peligro determinado que pueda afectar la decisión de fondo; es lo que la doctrina denomina periculum in mora $^{43}$. La adopción de esta decisión pre-

41 Véase CALDERón CUADRADO. Las medidas cautelares indeterminadas en el proceso civil, cit., 41 .

42 Cortez Matcovich, apoyándose para ello en Ortells Ramos, sostiene que debe distinguirse entre la situación jurídica cautelable y el fumus boni iuris, en tanto corresponden a presupuestos diversos. La primera obedece a la pretensión formulada en el proceso principal y en cuyo favor se establece la medida cautelar, en tanto que la segunda corresponde al proceso cognoscitivo que debe hacerse respecto de la situación jurídica en discusión. Véase Cortez Matcovich. Tutela cautelar en el proceso civil, cit., 78. La importancia de esta distinción es que toda medida cautelar que adopte el tribunal debe estar necesariamente vinculada a una situación jurídica cautelable en concreto que por ella se pretende asegurar. Véase ibid., 87-90. Así, la medida cautelar decretada debe necesariamente resultar idónea para tutelar dicha situación jurídica en específico. Véase ibid., 139-142.

43 Esto es, la amenaza de un perjuicio jurídico derivado del retardo en la decisión del asunto controvertido. Véase CALDERÓN CUADRADO. Las medidas cautelares indeterminadas en el proceso civil, cit., 45. 
ventiva requiere de motivos urgentes que justifiquen anticiparse a la decisión judicial definitiva ${ }^{44}$.

En línea con lo anterior, en este caso concreto, tratándose de una cuestión penal, la Corte concluye que la aplicación de una incautación de bienes debe ser imperiosa para "garantizar la investigación, el pago de las responsabilidades pecuniarias a que haya lugar o evitar la pérdida o deterioro de la evidencia".

La Corte plantea que la aplicación de esta clase de medidas debe respetar el criterio de la menor afectación y, por tanto, su adopción queda sujeta a un test previo de "inexistencia de otras medidas" menos gravosas ${ }^{45}$. De esta forma, solo resulta procedente decretar una medida cautelar real más restrictiva en tanto no se disponga de otra medida de afectación patrimonial menos intensa que permita alcanzar igual propósito ${ }^{46}$.

Por otra parte, las razones que llevan a adoptar la medida deben explicitarse. No se trata, entonces, solo de decisiones fundadas, sino de que los presupuestos que le sirven de justificación deben expresarse. A juicio de la Corte, "las autoridades nacionales están obligadas a dar razones" que justifiquen su aplicación concreta.

Las medidas cautelares son provisionales, en el criterio de la Corte, lo que coincide con la doctrina procesal ${ }^{47}$. Su adopción es interina, se trata de medidas temporales y no definitivas, de modo que su aplicación puede variar

44 Siguiendo la clasificación de Ortells Ramos y Calderón Cuadrado (véase nota 28), Jové sostiene que la aplicación de medidas cautelares anticipativas sigue un criterio más exigente que en el caso de las de aseguramiento y conservativas, para lo cual plantea un estándar de indispensabilidad. Señala que debe entenderse por "necesario" solo aquello que resulta indispensable o imprescindible para alcanzar un fin determinado. Ante cualquier solicitud cautelar de esta índole, el juez debe realizar una comprobación previa de que existe esa necesidad a fin de asegurar la efectividad del pronunciamiento definitivo. Véase Jové. Medidas cautelares innominadas en el proceso civil, cit., 127-131.

45 Para Cortez Matcovich este criterio de menor afectación se desprende del carácter instrumental de la medida cautelar y la necesaria idoneidad de esta última en orden a asegurar una situación jurídica cautelable concreta. Así, una determinada medida cautelar es idónea solo en tanto resulta proporcional a los riesgos que busca evitar y los perjuicios que ocasiona al afectado. La medida desproporcionada sobrepasa el fin de aseguramiento que persigue la tutela cautelar y, por tanto, no satisface adecuadamente dicho propósito. Véase Cortez Matcovich. Tutela cautelar en el proceso civil, cit., 139-142.

46 Jové explica que el criterio de la menor afectación, el que identifica como "principio de la mínima injerencia", obliga a que la medida cautelar a aplicar en el caso concreto sea la que resulte menos perjudicial para quien debe soportarla. Así, en materia cautelar lo asegurativo y conservativo debe preferirse por sobre lo satisfactivo e, incluso, en este último caso, limitarse a lo estrictamente necesario. En virtud de este principio, las medidas satisfactivas resultan, entonces, excepcionales y, de llegar a aplicarse, no pueden implicar la plena satisfacción de lo peticionado en el proceso principal, así como tampoco envolver efectos irreversibles. Véase ibid., 131-135.

47 CALAMANDREI. Introducción al estudio sistemático de las providencias cautelares, cit., 36. 
"si desaparecen las razones que justificaron la medida precautoria" ${ }^{4}$, debiendo cesar si no subsiste el peligro que motiva su imposición.

Nos parece importante señalar que, conforme al criterio de la Corte, las medidas cautelares quedan sujetas al control ulterior de parte del órgano jurisdiccional, pues "el juez debe valorar la pertinencia de continuar con la restricción, aún antes de la finalización del proceso". Empero, la sentencia no fija un criterio en torno a la periodicidad de dicha revisión.

En cuanto a la posibilidad de condicionar la devolución de los bienes incautados a un pago por concepto de custodia o administración, la Corte es tajante al rechazar esta posibilidad y expresa en el párrafo 193:

[E]l Tribunal resalta que las medidas cautelares reales se adoptan en relación con los bienes de una persona que se presume inocente, razón por la cual estas medidas no pueden perjudicar al sindicado en forma desproporcionada. El cobro efectuado a una persona sobreseída, en relación con los bienes que le fueron despojados provisoriamente, constituye una carga equivalente a una sanción. Esta exigencia resulta desproporcionada para aquellas personas cuya culpabilidad no fue demostrada. Sobre este punto el Estado señaló que "cuando se devuelve o se restituye un bien de propiedad de una persona que ha sido absuelta en un proceso penal" se "tiene[n] que pagar ciertos intereses por la custodia o administración que hace el Estado durante el tiempo que ha permanecido incautado"[,] lo cual "[e]s una clara arbitrariedad que debe ser corregida por el Estado ecuatoriano, a través de la respectiva reforma legal".

Por último, en los párrafos 202 a 218 la Corte rechaza -lo que parece de toda lógica- la omisión de entrega de bienes, el retraso en el cumplimiento de la sentencia que ordenó su devolución, así como la deficiente administración y custodia de los mismos, que derivó en su detrimento y en la subsecuente irrogación de perjuicios excesivos a los afectados.

48 En relación con la variabilidad de la resolución que decreta una medida cautelar, la doctrina procesal acusa dos posiciones contrapuestas. La primera de ellas niega lugar a la cosa juzgada en esta clase de resoluciones, las que considera, por tanto, esencialmente revocables; siempre están sujetas a una revisión por parte del tribunal que las otorgó, con independencia del agotamiento de la vía recursiva y la alteración de las condiciones que justificaron su otorgamiento. La segunda, en tanto, les reconoce el efecto de cosa juzgada, de modo que la variabilidad posterior de la resolución impositiva o denegatoria de una medida cautelar se funda en el cambio de las circunstancias que le sirvieron de fundamento, lo que supone un límite temporal a la cosa juzgada en virtud del principio rebus sic stantibus; véase CALDERÓN CUADRADO. Las medidas cautelares indeterminadas en el proceso civil, cit., 258-274. Como se lee en el párrafo 188 de la sentencia, la Corte parece reconocer el segundo criterio, esto es, el de variabilidad de la resolución cautelar en virtud del principio rebus sic stantibus. 
El presente caso se refiere a la responsabilidad internacional del Estado de Venezuela por la desprotección judicial frente a la persecución por parte de la policía del estado de Aragua sufrida por la familia Barrios, hechos que "se enmarcan en un contexto más general de ejecuciones extrajudiciales en Venezuela".

Producto de lo anterior, cinco miembros de la familia perdieron la vida y otros fueron sometidos a detenciones y allanamientos ilegales y arbitrarios, además de sufrir una serie de amenazas que los llevaron a "desplazarse de su lugar de residencia". Tales hechos incluso afectaron a niños y niñas.

El reproche a la propiedad -incidental, en consideración, por ejemplo, a la transgresión que se verificó al derecho a la vida e integridad física- se refiere a los allanamientos irregulares practicados por la policía sin una orden judicial previa, los que provocaron pérdida, destrucción e, incluso, incendio de bienes de los reclamantes.

En los párrafos 149 y 150 de la sentencia la Corte concluye abiertamente que por tales allanamientos se privó a sus titulares del derecho de propiedad en los siguientes términos:

[E]l Tribunal considera que el derecho de propiedad de [...] Barrios, [...] Barrios, [...] Alzul García y los familiares antes indicados [...] fue afectado por el hecho de que agentes policiales, durante el allanamiento de sus viviendas, retiraron electrodomésticos, dinero, medicamentos, ropa y artículos de higiene personal sin autorización, los cuales no fueron devueltos; destruyeron documentos, ropas y electrodomésticos, e incendiaron parcialmente la residencia de [...] Barrios y [...] Alzul García. Las víctimas fueron privadas injustificadamente de tales bienes y el Estado no controvirtió específicamente estos hechos ni proveyó explicaciones sobre lo ocurrido.

[...] Por lo anterior, la Corte concluye que el Estado violó el derecho a la propiedad privada reconocido en los artículos 21.1 y 21.2 de la Convención Americana, en relación con el artículo 1.1 del mismo instrumento.

Y en el párrafo 246 sostiene que, denunciados tales allanamientos, el Estado no efectuó una investigación oportuna:

En la investigación de los hechos no se realizaron inmediatamente diligencias relevantes para su esclarecimiento [...], teniendo en especial consideración que se trataba de hechos relativos a lugares habitacionales, por lo que una pronta y exhaustiva recolección de pruebas podría evitar la pérdida de las mismas.

A raíz de lo anterior, el párrafo 249 de la sentencia finaliza: 
En consecuencia, la Corte Interamericana concluye que las autoridades no actuaron con la debida diligencia en la investigación de los allanamientos, destrucción de bienes [e] incendio de las viviendas de [...] Barrios, [...] Alzul García, [...], [...] Barrios y [...]. Por ello, el Estado violó los derechos a las garantías y a la protección judiciales previstos en los artículos 8.1 y 25.1 de la Convención Americana, en relación con el artículo 1.1 de la misma.

Como se aprecia de los párrafos transcritos, la presente causa no atañe a una actuación judicial, sino más bien a la ausencia de esta. Sin embargo, resulta relevante para estos efectos advertir que la afectación de la propiedad se configura no solo por haberse practicado los allanamientos, sino también en orden a que, reclamados ante las autoridades judiciales, estas no intervinieron de manera efectiva.

En esta línea, el párrafo 248 señala:

[L]a Corte advierte que desde diciembre de 2003 a febrero de 2005 no se habrían realizado diligencias para el esclarecimiento de los hechos. Además, la Fiscalía solicitó, cinco años después de los hechos, información sobre los funcionarios policiales de la Comisaría Las Peñitas, diligencia requerida por el abogado de la familia Barrios, sin que dicha información conste en su auto de archivo fiscal, dictado tres días después de la solicitud.

De esta forma, la importancia de la sentencia en materia de propiedad radica especialmente en la atribución de consecuencias patrimoniales a la falta de intervención y control judicial: a la negación de control cautelar, en este caso. En efecto, el órgano jurisdiccional estatal no actuó diligentemente en la revisión de los hechos denunciados, pues no controló ni sancionó la afectación irregular de una serie de derechos de los involucrados, entre ellos la propiedad.

\section{MÉMOLI VS. ARGENTINA, 22 DE AGOSTO DE 2013}

El presente caso trata de una violación al derecho a la libertad de expresión de los señores Mémoli con ocasión de la condena penal impuesta en su contra como autores del delito de injurias, tras haber denunciado públicamente una supuesta venta irregular de nichos del cementerio local por parte de la comisión directiva de una asociación mutual de la ciudad de San Andrés de Giles.

En cuanto a la garantía a la propiedad, se reclama la existencia de medidas precautorias ordenadas respecto de bienes de propiedad de los afectados, que se extenderían por más de 14 años. Ello, en el marco de un proceso civil de indemnización de perjuicios seguido contra los señores Mémoli, como consecuencia de los hechos que motivaron su condena penal. 
La Corte advierte que el período de 15 años de duración del proceso civil parece excesivo. Razona que, si bien la cantidad de recursos interpuestos por ambas partes (alrededor de 30) puede haber dificultado la normal tramitación del procedimiento, existió una falta de diligencia de la autoridad judicial, circunstancia que resulta ser aún más gravosa en atención a la existencia de medidas cautelares reales decretadas (párrs. 172 a 178). En relación a las medidas cautelares expresa en el párrafo 180 de la sentencia:

[L]a Corte advierte que las autoridades judiciales internas no previeron la posibilidad de moderar el impacto de la duración del proceso civil en la facultad de las presuntas víctimas de disponer sus bienes, ni tomaron en cuenta que, según la legislación argentina[,] “[e]l juez, para evitar perjuicios o gravámenes innecesarios al titular de los bienes, podrá disponer una medida precautoria distinta de la solicitada, o limitarla, teniendo en cuenta la importancia del derecho que se intentare proteger".

Y concluye en el párrafo 183:

Todo esto demuestra que las autoridades judiciales a cargo no actuaron con la debida diligencia y el deber de celeridad que exigía[n] los derechos e intereses en juego. En definitiva, para la Corte la duración por más de quince años de un proceso civil de daños y perjuicios de naturaleza sumaria, fundamentado en una sentencia penal por un delito de injurias, aunado a la vigencia durante todo ese tiempo de una inhibición general de enajenar y gravar bienes, sobrepasa excesivamente el plazo que pudiera considerarse razonable para que el Estado resolviese un caso de esta naturaleza y afecta, de una manera desproporcionada, el derecho a la propiedad de los señores Mémoli. Con base en todo lo anterior, este Tribunal concluye que el Estado violó el principio del plazo razonable, establecido en el artículo 8.1[,] y el derecho a la propiedad privada, consagrado en el artículo 21, ambos en relación con el artículo 1.1, todos de la Convención Americana, en perjuicio de los señores [...] Mémoli.

Así, la sentencia reitera el criterio de la menor afectación, anunciado tiempo antes en Chaparro Álvarez y Lapo Íñiguez vs. Ecuador, pero esta vez lo desarrolla en torno a la necesidad de ponderar la duración de la medida cautelar aplicada. A fin de evitar perjuicios innecesarios al titular de los bienes, plantea el deber judicial de moderar el impacto de la afectación y califica como una falta de diligencia su dilatada extensión en el tiempo.

La limitación a la propiedad que entraña toda medida cautelar -en principio tolerada por la Convención- se torna ilegítima cuando su duración se 
extiende más allá del tiempo considerado razonable y, a juicio de la Corte, lesiona el dominio de "una manera desproporcionada" 49 .

Además, la Corte reitera la necesidad de que el juez cautelar efectúe un test previo de inexistencia de otras medidas menos gravosas, "para evitar perjuicios o gravámenes innecesarios al titular de los bienes". El juez no queda constreñido en esta materia por la petición del solicitante de cautela, de modo que puede adoptar medidas diversas y menos lesivas.

Resulta interesante destacar que el test de inexistencia de medidas menos gravosas es exigido en este caso por la Corte a propósito de una medida que, en la clasificación de Ortells Ramos y Calderón Cuadrado ${ }^{50}$, obedece a una de carácter asegurativo. De esta forma, dicho test corresponde a una condición de ejercicio de la jurisdicción cautelar en general, y no es aplicable solo al caso de las medidas calificadas como satisfactivas.

\section{ANDRADE SALMÓN VS. BOLIVIA, 1 DE DICIEMBRE DE 2016}

Se trata de la responsabilidad internacional de Bolivia por violaciones a los derechos humanos cometidas con ocasión de tres procesos penales (casos $\mathrm{Ga}$ der, Luminarias Chinas y Quaglio), seguidos en contra de la señora Andrade Salmón por supuestas conductas ilícitas relacionadas con la administración de fondos públicos.

Dichas violaciones a los derechos humanos descansan en la actuación deficiente de las autoridades judiciales, las cuales no realizaron actos procesales significativos para resolver los procesos penales antes indicados, dentro de un tiempo razonable.

En dos de dichos procesos penales se decretó la prisión preventiva de la víctima, sin fundamento suficiente, a la vez que esta tampoco dispuso de recursos procesales adecuados y efectivos para discutir dicha medida cautelar personal. También se cuestiona la circunstancia de haber permanecido la afectada sujeta a una medida de arraigo nacional que se extendió por más de 10 años.

En lo que se refiere a la propiedad, el reproche versa sobre el hecho de que, al alero de tales procesos penales, se fijaron medidas cautelares reales sustitutivas de la prisión preventiva, sin ofrecer fundamento acerca de los montos en que estas fueron fijadas y sin atender para ello a las condiciones económicas de la afectada. La Corte sostuvo en los párrafos 111 y 112 de la sentencia:

49 En este sentido, la Corte parece reconocer la necesidad de seguir un criterio de proporcionalidad entre la situación jurídica concreta cautelada y los perjuicios que por la aplicación de la medida cautelar se ocasionan al afectado, a lo que Cortez Matcovich se refiere como idoneidad de la medida cautelar. CoRTEZ MATCOVICH. Tutela cautelar en el proceso civil, cit., 139-142.

50 Véase nota 28. 
[R] esulta necesario reiterar que el derecho a la propiedad no es absoluto y, en ese sentido, puede ser objeto de restricciones y limitaciones, siempre y cuando éstas se realicen por la vía legal adecuada y de conformidad con los parámetros establecidos en el artículo 21. El primer párrafo de dicho artículo se refiere al derecho a la propiedad privada, y señala como atributos de la propiedad el uso y goce del bien e incluye una limitación a dichos atributos de la propiedad en razón del interés social. A su vez, el segundo inciso se refiere a la expropiación de bienes y los requisitos para que tal actuar del Estado pueda considerarse justificado [...].

[...] [E]n lo que se refiere a las medidas cautelares sustitutivas de la privación a la libertad previa a una sentencia, dentro de las cuales se podrían enmarcar las medidas de fianza, el artículo 7.5 de la Convención establece que "[t]oda persona detenida o retenida debe ser llevada, sin demora, ante un juez u otro funcionario autorizado por la ley para ejercer funciones judiciales y tendrá derecho a ser juzgada dentro de un plazo razonable o a ser puesta en libertad, sin perjuicio de que continúe el proceso. Su libertad podrá estar condicionada a garantías que aseguren su comparecencia en el juicio".

Luego de reiterar la premisa de que la imposición de una medida cautelar real configura una afectación a la propiedad tolerada por la Convención y, por ende, que su aplicación no constituye per se una transgresión a la misma, la Corte advierte que ello no importa una autorización ilimitada, y ahonda nuevamente en las condiciones que deben cumplir tales medidas para no devenir en inconvencionales. Para ello, esta vez centra su análisis en dos líneas: 1. La necesidad y proporcionalidad de la medida, en atención a la capacidad económica del imputado, y 2. La duración y revisión de la misma en el tiempo. En cuanto a la necesidad y proporcionalidad, la Corte sostiene en el párrafo 124:

[L]as autoridades judiciales que ordenan medidas cautelares de fianza sustitutivas a la prisión preventiva, deben tomar en consideración en el análisis de la necesidad y de la proporcionalidad de la medida que se impone, el hecho [de] que en otros procesos puedan haber sido impuestas medidas cautelares de la misma naturaleza.

En esta línea, la Corte alude nuevamente a la "necesidad de la medida" como condición para su otorgamiento, ya expresado en Chaparro Álvarez y Lapo Íniguez vs. Ecuador. Se confirma de esta manera el criterio jurisprudencial antedicho, en orden a que el otorgamiento de esta clase de medidas queda, entonces, sujeto a un estándar de necesidad o indispensabilidad ${ }^{51}$.

51 La necesidad como condición de afectación iusfundamental conlleva estimar que no se dispone de otros medios que restrinjan menos lesivamente tal derecho fundamental en específico, de modo que, produciéndose cierta pérdida, esta no haya podido evitarse por la implementación 
Cabe destacar que para la Corte el test de indispensabilidad debe tomar en cuenta la circunstancia de que "en otros procesos puedan haber sido impuestas medidas cautelares de la misma naturaleza". Ello nos lleva prima facie a concluir que, si bien los procesos principales pueden ser independientes, los de índole cautelar, en cambio, serían comunicables.

Ahora bien, esta obligación de "tomar en cuenta" no equivale a afirmar que la sola existencia de una medida cautelar vigente determina la absoluta imposibilidad de aplicar una medida similar en otro proceso distinto, pues esto iría más allá de lo afirmado por la Corte. La instrumentalidad ínsita de toda medida cautelar liga su otorgamiento al aseguramiento de un proceso principal en concreto, cuestión que no queda en entredicho.

La existencia de otras medidas cautelares reales vigentes debe ser estimada únicamente para efectos de ponderar el impacto patrimonial ocasionado al afectado con la aplicación de la nueva medida; pues, dada su situación particular, puede resultar en extremo gravosa y llevar al juez cautelar a considerarla innecesaria, como en el caso de fijar una fianza cuando el imputado carece de otros bienes disponibles por encontrarse todos ya afectos a fianza.

De esta manera, para determinar la necesidad de una medida se debe atender a todos los elementos relevantes que configuran la situación particular de quien la soporta, lo que supone también considerar la existencia de otras medidas cautelares vigentes, incluso si fueron impuestas en virtud de procesos judiciales distintos; circunstancia esta última que, en todo caso, no conlleva la inmediata imposibilidad de aplicar una nueva medida.

En cuanto a la proporcionalidad, reitera el criterio esbozado en Mémoli $v s$. Argentina, en orden a que el juez cautelar debe ponderar el perjuicio que la aplicación de la medida irroga al afectado. No obstante, en esta ocasión ahonda expresamente en la necesidad de considerar la capacidad económica del afectado y la obligación del tribunal de tomar efectivo conocimiento acerca de esta al momento de efectuar la ponderación.

De tal forma, la estimación del impacto que la medida cautelar real tiene para el afectado debe ser establecida en relación con la capacidad patrimonial de este último, considerada por el juez cautelar en términos efectivos. Se refiere a ello la sentencia en sus párrafos 125 y 126 :

El alegato del Estado de acuerdo al cual las posibilidades de pago de la señora Andrade eran de público conocimiento [...] no puede constituir, por sí solo, un criterio para que la autoridad tome una decisión con la finalidad de imponer una medida cautelar restrictiva de un derecho, en este caso, el de propiedad.

de una medida distinta. Véase LeIva Rabael, A. Proporcionalidad y justicia constitucional. Santiago: Libromar, 2018, 121. 
[...] [L]as autoridades bolivianas ordenaron la imposición de esas medidas sin contar con elementos para ello, por lo que no efectuaron el análisis de proporcionalidad de la medida restrictiva al derecho de propiedad. Sin perjuicio de ello, [...] en una segunda instancia, modificaron el monto de la fianza para ajustarla a sus capacidades de pago [...] En ese sentido, habrían corregido las falencias de las primeras decisiones para ajustarlas a las posibilidades reales de cumplimiento por parte de la señora Andrade.

La sentencia aporta así un nuevo criterio con respecto a la proporcionalidad en la tutela cautelar, al plantear abiertamente que la medida en cuestión -en este caso, la fianza sustitutiva de la prisión preventiva- ha de ser establecida en consideración a las capacidades económicas del imputado, lo que el juez cautelar debe expresar al momento de determinar su quantum.

En segundo término, acerca de la duración de las medidas, la Corte precisa en el párrafo 133:

En el caso "Gader" las medidas cautelares impuestas estuvieron vigentes durante un período de 11 años. En el caso "Luminarias Chinas", no se cuenta con información sobre el reintegro de la fianza fijada y pagada en el año 2000, es decir más de 16 años después de haber sido impuestas. A lo largo de esos procesos, no se han presentado elementos de análisis que puedan justificar que esas medidas restrictivas al derecho de propiedad se extendieran por períodos tan prolongados. En ese sentido, se puede concluir que la imposición de medidas de carácter temporal que afectan el uso y goce de los bienes de una persona por períodos de tiempo tan extensos sin que se haga una revisión periódica de las mismas, no resulta razonable. En consecuencia, esta Corte encuentra que el Estado es responsable por la violación del derecho de propiedad contenido en el artículo 21 de la Convención en relación con los artículos 7.5 y 1.1 del mismo instrumento.

Reitera de esta forma el criterio expuesto en Mémoli vs. Argentina, en el sentido de que la extensión innecesaria de una medida cautelar en el tiempo constituye una afectación infundada que, por tanto, resulta inconvencional. Se vuelve ilegítima la medida cautelar cuya duración se extiende más allá del tiempo considerado razonable, pues lesiona el dominio de una forma desproporcionada.

No obstante, agrega un criterio adicional en esta materia. Sostiene la Corte que, a fin de evitar toda extensión innecesaria, recae sobre el juez cautelar la obligación de someter la medida concedida a una revisión periódica. Así, si bien en Chaparro Álvarez y Lapo Íñiguez vs. Ecuador la Corte reconoció la necesidad de someter las medidas cautelares a un control judicial posterior ${ }^{52}$, en esta ocasión agrega la periodicidad como cualidad de este último.

52 Véase Chaparro Álvarez y Lapo Íñiguez vs. Ecuador. Excepciones Preliminares, Fondo, Reparaciones y Costas. Sentencia del 21 de noviembre de 2007, párr. 188. 
De esta manera, tenemos que el juez cautelar se encuentra obligado a sujetar el otorgamiento de una medida cautelar real a una revisión ulterior de carácter periódico, destinada a establecer si persisten los presupuestos que determinaron la necesidad de aplicación de tal medida, a fin de evaluar su mantención, modificación o cese.

\section{CONCLUSIÓN}

De la revisión de sentencias de fondo dictadas por las Corte Interamericana de Derechos Humanos en materia de afectación de la propiedad privada, por la actividad jurisdiccional relacionada con la aplicación de medidas cautelares reales, pueden identificarse importantes líneas jurisprudenciales.

Queda de manifiesto que dicho órgano jurisdiccional interamericano sostiene una noción amplia de propiedad y que su interpretación no se limita a la expresión literal del artículo 21 de la Convención, sino que comprende toda clase de bienes, tanto corporales como incorporales, así como el contenido económico derivado de otros derechos, como el derecho de autor (Palamara Iribarne vs. Chile).

Esto nos permite afirmar que toda relación jurídica de carácter patrimonial queda amparada por la garantía a la propiedad, incluso cuando dicha relación económica deriva de elementos morales, como ocurre con la paternidad y la integridad de la obra en el derecho de autor.

En el plano judicial cautelar, la garantía convencional a la propiedad comprende también la posesión de los bienes, de modo que la apariencia de dominio obliga a presumir su titularidad. Lo anterior impide a los Estados sujetar la devolución de los bienes objeto de medidas cautelares a la necesidad de que los poseedores acrediten previamente el dominio sobre los mismos (Tibi vs. Ecuador).

Dicha conclusión se extiende también a los bienes sometidos a sistemas de registro, aunque en estos casos la Corte requiere, además, la ausencia de un tercero opositor. Señalamos que la extensión de tal razonamiento al caso de bienes en que la inscripción constituye un requisito de la posesión plantea algunas dudas, que esperamos puedan aclararse a partir de las decisiones futuras de la Corte en esta materia.

Las medidas cautelares no configuran prima facie una privación de la propiedad, en tanto por ellas no se provoca un cambio en la titularidad del dominio, pero evidentemente restringen el derecho del propietario, pues afectan sus facultades de administración y disposición (Chaparro Álvarez y Lapo Íñiguez vs. Ecuador).

Así, resulta patente que la aplicación de tales medidas no constituye per se una contravención a la Convención y que los Estados están facultados para aplicarlas legítimamente. No obstante, el ejercicio de la potestad cautelar 
queda sujeto al cumplimiento de ciertas condiciones, cuya transgresión lo torna ilegítimo y puede irrogar responsabilidad patrimonial.

El primero de ellos se refiere a la necesidad de materializarse por medio de decisiones fundadas, que den cuenta de las razones que llevaron a su adopción concreta. Señala la Corte que la aplicación de una medida cautelar debe estar amparada en una apariencia de buen derecho o fumus boni iuris; una situación jurídicamente cautelable, debidamente examinada por el Tribunal (Chaparro Álvarez y Lapo Íñiguez vs. Ecuador).

El propósito de estas medidas consiste en precaver un perjuicio derivado de la pendencia en la obtención de una decisión judicial definitiva en un proceso principal o periculum in mora, de modo que obedecen a motivos urgentes. La intervención cautelar debe resultar, entonces, necesaria (Chaparro Álvarez y Lapo Íñiguez vs. Ecuador, Mémoli vs. Argentina, Andrade Salmón vs. Bolivia).

La indispensabilidad de la medida debe ser resuelta en atención a todos los elementos relevantes que configuran la situación particular de quien la soporta, lo que obliga a considerar la existencia de otras medidas cautelares vigentes, incluso si fueron impuestas en virtud de procesos judiciales distintos (Andrade Salmón vs. Bolivia).

Las medidas deben sujetarse al criterio de la menor afectación, a fin de que por ellas se ocasione el menor perjuicio posible al titular de los bienes. Esto obliga a someterlas a un test previo de inexistencia de otras medidas menos gravosas, lo que constituye un presupuesto general de toda la jurisdicción cautelar, y a evaluar su sustitución cuando signifique una menor injerencia (Chaparro Álvarez y Lapo Íñiguez vs. Ecuador, Mémoli vs. Argentina).

Por la misma razón, la aplicación de estas medidas debe resultar proporcional. Su establecimiento ha de considerar la capacidad económica efectiva del afectado (Andrade Salmón vs. Bolivia), a la vez que el juez cautelar queda obligado a ponderar el impacto que su duración provoca el patrimonio de este, pues su excesiva prolongación temporal puede tornarlas en desproporcionadas (Mémoli vs. Argentina).

Al tratarse de medidas provisionales, deben cesar si desaparecen los presupuestos que motivaron su aplicación. Por esta razón el juez cautelar se encuentra obligado a ejercer sobre estas una revisión periódica. La ausencia de control cautelar irroga responsabilidad patrimonial al Estado (Familia Barrios vs. Venezuela), así como también su excesiva dilación en el tiempo (Mémoli vs. Argentina).

Por último, cabe señalar que cuando las medidas cautelares configuran una privación del dominio y no una simple restricción, devienen en una expropiación material. Para que una expropiación se ajuste a la Convención debe ser decretada en conformidad con la ley y fundarse en razones de utilidad pública o de interés social (Palamara Iribarne vs. Chile). 
A nuestro entender, todas estas sentencias permiten identificar una línea jurisprudencial consistente de la Corte Interamericana, en orden a rechazar las afectaciones a la propiedad que puedan ser provocadas por actuaciones judiciales fuera de los límites precedentemente indicados, y a establecer las condiciones que justifican el ejercicio de la tutela cautelar.

\section{REFERENCIAS}

Calamandrei, P. Introducción al estudio sistemático de las providencias cautelares. Santiago: Olejnik, 2018.

Caldera Delgado, H. Tratado de derecho administrativo. T. II. Santiago: Parlamento, 2001.

Calderón Cuadrado, M. P. Las medidas cautelares indeterminadas en el proceso civil. Madrid: Civitas, 1992

Carnelutti, F. Instituciones del proceso civil. Vol. III (1956). 5. a ed. Trad. S. Sentís Melendo. Buenos Aires: EJEA, 1973.

Cea Egaña, J. L. Tratado de la Constitución de 1980. Santiago: Jurídica de Chile, 1988.

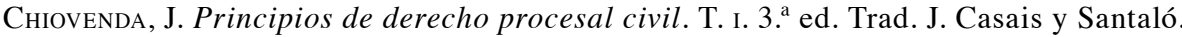
Madrid: Reus, 1922.

Corral Talciani, H. Curso de derecho civil. Bienes. Santiago: Thomson Reuters, 2020.

Cortez Matcovich, G. Tutela cautelar en el proceso civil. Santiago: Thomson Reuters, 2017.

Espejo Yaksic, N. y Leiva García, C. Digesto de jurisprudencia de la Corte Interamericana de Derechos Humanos (enero de 1984-febrero de 2012). Santiago: Thomson Reuters, 2012.

Evans de la Cuadra, E. Los derechos constitucionales. T. III. 3. a ed. Santiago: Jurídica de Chile, 1999.

Fermandois V., A. Derecho constitucional económico. T. II. Santiago: Universidad Católica de Chile, 2010.

Ferrero Hernández, R. Protección de la propiedad comunal indígena por la Corte Interamericana. En Revista IIDH. Vol. 63, 2016, 65-103.

Fuentes Olmos, J. El derecho de propiedad. Santiago: DeR, 2018.

García de Enterría, E. y Fernández, T. R. Curso de derecho administrativo. T. il. 15. a ed. Madrid: Thomson Civitas, 2006, 120.

Jové, M. Á. Medidas cautelares innominadas en el proceso civil. Barcelona: Bosch, 1995.

Leiva Rabael, A. Proporcionalidad y justicia constitucional. Santiago: Libromar, 2018.

López EsCARCENA, S. La propiedad y su privación o restricción en la jurisprudencia de la Corte Interamericana. En Revista Ius et Praxis. Año 21, n. ${ }^{\circ}$ 1, 2015, 531-576. 
López Escarcena, S. Un derecho jurisprudencial. La propiedad colectiva y la Corte Interamericana. En Revista de Derecho Universidad Católica del Norte. Año 24, n. ${ }^{\circ}$ 1, 2017, 133-189.

Montory Barriga, G. J. La propiedad constitucional: limitaciones, privaciones, contenido esencial. Valencia: Tirant lo Blanch, 2019.

Nogueira Alcalá, H. Derechos fundamentales y garantías constitucionales. T. iv. 2. ed. Santiago: Librotecnia, 2013.

Orellana Torres, F. Manual de derecho procesal. T. II, Procedimientos civiles ordinarios y especiales. Santiago: Librotecnia, 2008.

Ortells Ramos, M. Las medidas cautelares. Madrid: La Ley, 2000.

Ortells Ramos, M. y Calderón CuAdrado, M. P. La tutela judicial cautelar en el derecho español. Granada: Comares, 1996.

Peñailillo Arévalo, D. Los bienes. La propiedad y otros derechos reales. 2. a ed. Santiago: Thomson Reuters, 2019.

Pereira Anabalón, H. Curso de derecho procesal. T. i. Santiago: Jurídica Conosur, 1993.

Pérez Ragone, Á. y Hormazábal Riquelme, D. El embargo de cuentas bancarias. En Revista de Derecho Universidad Católica del Norte. Año 22, n. ${ }^{\circ}$ 1, 2015, 307-350.

Ponce Correa, P. La expropiación en su manifestación judicial. Santiago: Librotecnia, 2011.

Quezada Meléndez, J.Derecho procesal civil chileno. La jurisdicción. Santiago: Ediar, 1984.

Roy Pérez, C. Las medidas cautelares en el proceso civil. Barcelona, Bosch, 2007.

Santaella Quinteros, H. La propiedad privada constitucional: una teoría. Madrid: Marcial Pons, 2019.

Vivanco Martínez, Á. Curso de derecho constitucional. Aspectos dogmáticos de la Carta Fundamental de 1980. T. II. Santiago: Universidad Católica de Chile, 2006.

Vodanovic Haklicka, A. Tratado de los derechos reales. Bienes. T. i. Basado en las explicaciones de clases de Arturo Alessandri Rodríguez y Manuel Somarriva Undurraga. 7. ${ }^{a}$ ed. Santiago: Jurídicas de Santiago, 2016, 422.

Walker Echenique, E. Manual de propiedad intelectual. Santiago: Legal Publishing Chile, 2014.

\section{Jurisprudencia de la Corte Interamericana de Derechos Humanos}

Comunidad Mayagna (Sumo) Awas Tingni vs. Nicaragua. Sentencia del 31 de agosto de 2001.

Cinco pensionistas vs. Perú. Sentencia del 28 de febrero de 2003.

Comunidad Moiwana vs. Suriname. Sentencia del 15 de junio de 2005.

Comunidad indígena Yakye Axa vs. Paraguay. Sentencia del 17 de junio de 2005. 
Afectación de la propiedad privada por la incautación de bienes y otras medidas...

Palamara Iribarne vs. Chile. Sentencia del 22 de noviembre de 2005.

Comunidad indígena Sawhoyamaxa vs. Paraguay. Sentencia del 29 de marzo de 2006.

Masacres de Ituango vs. Colombia. Sentencia del 1 de julio de 2006.

Pueblo Saramaka vs. Surinam. Sentencia del 28 de noviembre de 2007.

Salvador Chiriboga vs. Ecuador. Sentencias del 6 de mayo de 2008 (Excepción Preliminar y Fondo), del 3 de marzo de 2011 (Reparación y Costas) y del 29 de agosto de 2011 (Interpretación).

Perozo y otros vs. Venezuela. Sentencia del 28 de enero de 2009.

Acevedo Buendía y otros ('Cesantes y Jubilados de la Contraloría') vs. Perú. Sentencia del 1 de julio de 2009.

Comunidad indígena Xákmok Kásek vs. Paraguay. Sentencia del 24 de agosto de 2010.

Abrill Alosilla y otros vs. Perú. Sentencia del 4 de marzo de 2011.

Pueblo indígena Kichwa de Sarayaku vs. Ecuador. Sentencia del 27 de junio de 2012.

Furlan y familiares vs. Argentina. Sentencia del 31 de agosto de 2012.

Masacre de Santo Domingo vs. Colombia. Sentencia del 30 de noviembre de 2012.

Mémoli vs. Argentina. Sentencia del 22 de agosto de 2013.

Pueblos indígenas Kuna de Madungandí y Emberá de Bayano y sus miembros vs. Panamá. Sentencia del 14 de octubre de 2014.

Comunidad Garífuna Triunfo de la Cruz y sus miembros vs. Honduras. Sentencia del 8 de octubre de 2015.

Comunidad Garífuna de Punta Piedra y sus miembros vs. Honduras. Sentencia del 8 de octubre de 2015.

Pueblos Kaliña y Lokono vs. Surinam. Sentencia del 25 de noviembre de 2015. 